\title{
PRINCIPAIS DOENÇAS DA CULTURA DA SOJA E MANEJO INTEGRADO
}

\author{
ITO, Margarida Fumiko ${ }^{1}$
}

ISSUE DOI: $10.3738 /$ nucleus.v0i0.908

\begin{abstract}
RESUMO: Muitas doenças já foram relatadas na cultura da soja, porém a incidência e severidade dependem de alguns fatores, como clima, cultivares, potencial de inóculo de patógenos, estrutura e fertilidade do solo, vigor da planta, dentre outros. O cenário das doenças na cultura da soja no Brasil vem se alterando a cada ano, com o aumento da severidade de algumas doenças, tanto da parte aérea, como as causadas por fungos habitantes do solo. A maioria dos patógenos bacterianos e fúngicos é transmitida ou transportada pelas sementes. As principais doenças bacterianas são crestamento bacteriano, fogo selvagem e pústula bacteriana. Essas doenças encontram-se controladas através do uso de cultivares de soja com maior nível de resistência genética aos seus patógenos. As doenças causadas por fungos são a maioria na cultura. A ocorrência das doenças pode variar de safra a safra, de região a região e a maior ou menor severidade depende das condições climáticas, cultivar de soja em uso e potencial de inóculo do patógeno. Algumas doenças têm requerido controle químico, como as doenças de fim de ciclo, oídio, mofo branco e ferrugem. A ferrugem tem proporcionado altos custos ao seu controle com fungicidas, há mais de uma década. Nas últimas safras, o mofo branco também tem ocorrido em muitas culturas, com necessidade do uso de fungicidas. Nesta palestra são apresentadas as principais doenças da cultura da soja, seus sintomas e o manejo integrado ao controle de doenças.
\end{abstract}

Palavras-chave: Glycine max, patógenos, controle

\section{INTRODUÇÃO}

A soja foi introduzida no Brasil em 1882, vindas dos Estados Unidos e Gustavo Dutra realizou os primeiros estudos de avaliação de cultivares. O Instituto Agronômico (IAC) introduziu as primeiras sementes de soja no Estado de São Paulo em 1889 (D’Utra, 1989 a, b) e iniciou as pesquisas com testes de adaptação de cultivares em 1891(CAVALCANTI, 1892; DAFFERT, 1892). Uma década após, em 1900 e 1901, o IAC encaminhou as sementes de soja à Secretaria de Agricultura, para distribuir aos agricultores do Estado de São Paulo (SECRETARIA, 1900; 1901) e na década de 50, o IAC iniciou o programa de pesquisa de soja (MASCARENHAS et al., 1974).

A partir da década de 60 a soja tomou importância econômica no Brasil, foi conquistando mercado e alcançou o patamar de constituir-se numa das mais importantes commodities produzidas e comercializadas pelo Brasil, contribuindo com a entrada de grande parte do PIB todos os anos. No entanto, a sua produção acarreta altos custos ao produtor e ao País, com gastos para a aquisição de insumos e, desde a constatação da ferrugem, já há mais de uma década, os fungicidas representam alto investimento destinado ao controle da principal doença da cultura; faltam cultivares de soja com maior nível de resistência genética ao fungo Phakopsora pachyrhizi, patógeno causador dessa ferrugem, como também para outras doenças.

O cenário das doenças na cultura da soja no Brasil vem se alterando a cada ano, com o aumento da severidade de algumas doenças, tanto da parte aérea, como as causadas por fungos habitantes do solo.

\footnotetext{
${ }^{1}$ Pesquisadora Científica, Dra. - Centro de Pesquisa e Desenvolvimento de Fitossanidade - Instituto Agronômico IAC/APTA/SAA, Caixa Postal 28 - CEP: 13020-902 Campinas - SP. E-mail: mfito@iac.sp.gov.br
} 
Muitas doenças podem ocorrer na cultura da soja (FERREIRA et al., 1979; SINCLAIR, 1982; EMBRAPA, 2011), e a ferrugem e o mofo branco são as doenças que vêm causando altos custos ao seu controle com fungicidas, além de perdas na produção e qualidade da soja. Outras doenças, em condições favoráveis ao seu desenvolvimento, têm sido controladas na parte aérea pelo uso de fungicidas, como as doenças de final de ciclo, a mancha alvo e o oídio.

O eficiente controle das doenças depende do seu correto manejo, incluindo-se o controle químico quando necessário, no momento certo e de forma adequada.

\section{Doenças causadas por bactérias}

As principais doenças bacterianas na cultura da soja são crestamento bacteriano, fogo selvagem e pústula bacteriana (Tabela 1).

\subsection{Crestamento bacteriano - Pseudomonas savastanoi pv. glycinea (Coerper) Young, Dye \& Wilkie}

A doença crestamento bacteriano é causada pela bactéria Pseudomonas savastanoi pv. glycinea. Essa doença pode ocorrer em regiões produtoras de soja que apresentem as condições ideais ao seu desenvolvimento, que são alta umidade e temperatura amena, de $20^{\circ} \mathrm{C}$ a $26^{\circ} \mathrm{C}$.

Os sintomas podem aparecer em toda parte aérea, mas são mais comuns nas folhas, no período do florescimento (Fig. 1 A). Em condições muito favoráveis à doença, pode afetar as vagens e as sementes. Essas sementes podem ser menores, mais leves e transmitir a bactéria.

A maioria das cultivares em uso apresenta resistência genética à bactéria. Assim, não se tem relatos de grandes perdas por essa doença.

Como medidas de controle são recomendadas uso cultivares com resistência e sementes sadias, rotação de culturas e evitar práticas culturais quando o ambiente da cultura estiver com alta umidade.

\subsection{Fogo selvagem - Pseudomonas syringae pv. tabaci (Wolf \& Foster) Young, Dye \& Wilkie}

Fogo selvagem é causada pela bactéria Pseudomonas syringae pv. tabaci. Essa doença pode ocorrer em regiões produtoras de soja quando ocorrem condições climáticas favoráveis ao seu desenvolvimento: alta umidade e temperatura entre $24^{\circ} \mathrm{C}$ a $28^{\circ} \mathrm{C}$. Pode ocorrer juntamente ao crestamento bacteriano e ou à pústula bacteriana.

Os sintomas podem aparecer em toda parte aérea, mas são mais comuns nas folhas, no período do florescimento. O sintoma típico é mancha necrótica com grande halo amarelo (Fig. 1 B). Sementes produzidas por plantas afetadas por essa doença podem ser menores, mais leves e transmitir a bactéria.

A maioria das cultivares em uso apresenta resistência genética à bactéria. Assim, não se tem relatos de grandes perdas por essa doença.

Como medidas de controle são recomendadas uso de cultivares com resistência e sementes sadias, rotação de culturas e evitar práticas culturais quando o ambiente da cultura estiver com alta umidade.

\subsection{Pústula bacteriana - Xanthomonas axonopodis pv. glycines (Smith) Dye}

É causada pela bactéria Xanthomonas axonopodis pv. glycines, pode ocorrer em todas as regiões produtoras de soja. As condições ideais ao seu desenvolvimento são alta umidade e alta temperatura, de $28^{\circ} \mathrm{C}$ a $30^{\circ} \mathrm{C}$. 
Os sintomas podem aparecer em toda parte aérea, mas são mais comuns nas folhas, no período do florescimento (Fig. 1 C). Em condições muito severas, pode afetar as vagens e as sementes. Sementes produzidas por plantas afetadas por essa doença podem ser menores, mais leves e transmitir a bactéria.

A maioria das cultivares em uso apresenta resistência genética à bactéria. Assim, não se tem relatos de grandes perdas por essa doença.

Como medidas de controle são recomendadas uso de cultivares com resistência e sementes sadias, rotação de culturas e evitar práticas culturais quando o ambiente da cultura estiver com alta umidade.

Figura 1. Doenças bacterianas em soja. A. Sintomas de crestamento bacteriano (Pseudomonas savastone pv. glicynea). B. Sintomas de fogo selvagem (Pseudomonas syringae pv. tabaci). C. Sintomas de pústula bacteriana (Xanthomonas axonopodis pv. phaseoli).
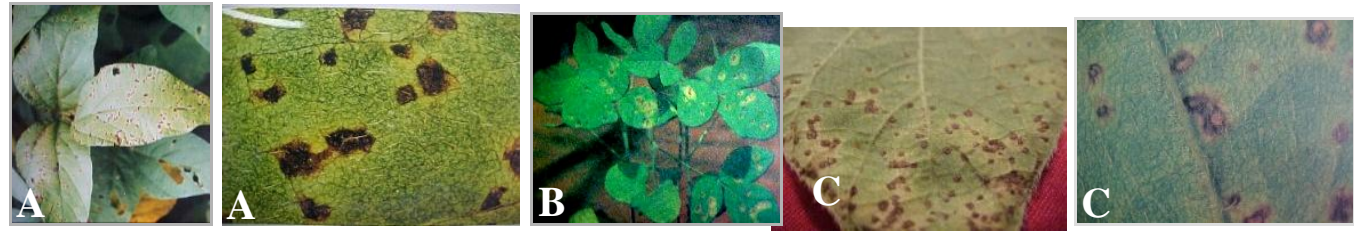

Tabela 1. Principais doenças (patógeno causador) bacterianas da cultura da soja, agentes de disseminação, condições favoráveis e forma de sobrevivência.

\begin{tabular}{llll}
\hline Doença & Agentes de disseminação & Condições favoráveis & $\begin{array}{l}\text { Sobrevivência do } \\
\text { patógeno }\end{array}$ \\
\hline Crestamento & Vento, chuva, insetos, & Temperatura entre & $\begin{array}{l}\text { Sementes e restos de } \\
\text { cultura }\end{array}$ \\
bacteriano & sementes e implementos & $20^{\circ} \mathrm{C} \mathrm{a} 26^{\circ} \mathrm{C}$ & Alta umidade
\end{tabular}

savastanoi pv.

glycinea)

Fogo selvagem

Vento, chuva, insetos,

Temperatura entre

Sementes e restos

(Pseudomonas animais, implementos $24^{\circ} \mathrm{C}$ a $28^{\circ} \mathrm{C}$ de cultura

syringae pv. tabaci) agrícolas e sementes

Alta umidade

Pústula bacteriana

(Xanthomonas axonopodis pv.

Vento, chuva, insetos,

Alta temperatura,

Sementes e restos animais, implementos entre $28^{\circ} \mathrm{C}$ a $30^{\circ} \mathrm{C}$ de cultura glycines) agrícolas e sementes

Alta umidade

Compilado segundo Sinclair, 1982; ITO, 2005.

\section{Doenças causadas por fungos}

\subsection{Parte aérea}

Na parte aérea das plantas de soja podem ocorrer muitas doenças, dependendo das condições de temperatura e umidade ideais para o desenvolvimento de cada patógeno (Tabela 2).

\subsubsection{Antracnose - Colletotrichum truncatum (Schw.) Andrus \& Moore}

A antracnose, causada pelo fungo Colletotrichum truncatum, sin. C. dematium (Pers. ex Fr.) Grove var. truncata (Schw.) Arx, está amplamente distribuída nas regiões produtoras de soja no Brasil. 
Tem causado maiores problemas em regiões mais quentes e nas colheitas afetadas por chuvas. O fungo pode afetar toda a parte aérea da planta e no início da cultura, o patógeno $C$. truncatum pode causar tombamento de pré e pós-emergência (Fig. 2 A e B).

As condições ideais ao desenvolvimento da antracnose são alta temperatura, entre $28^{\circ} \mathrm{C}$ a $34^{\circ} \mathrm{C} \mathrm{e}$ alta umidade.

Os sintomas podem aparecer em toda parte aérea da planta, em qualquer estádio. Nas folhas, podem aparecer manchas necróticas e escurecimento das nervuras. As sementes podem ser infectadas e transmitir o fungo.

Para o controle da antracnose recomenda-se o uso de sementes sadias, tratamento de sementes com fungicidas conforme necessidade, incorporação de restos culturais, rotação de culturas, dentre outras medidas.

Cinco fungicidas estão registrados ao controle da antracnose: flutriafol + tiofanato metílico (celeiro), carbendazim (mandarim), fipronil + piraclostrobina + tiofanato metílico (source top), fipronil + piraclostrobina + tiofanato metílico (standak top) e ciproconazol + trifloxistrobina (sphere max).

Figura 2. Sintomas de antracnose em soja, causada por Colletotrichum truncatum. A. Mancha necrótica e escurecimento da nervura. B. Lesão no cotilédone.
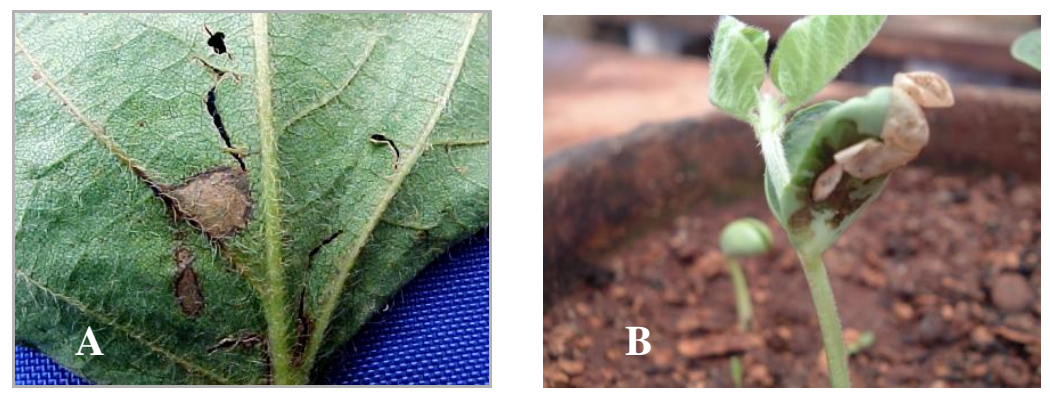

\subsubsection{Cancro da haste - Diaporthe phaseolorum f. sp. meridionalisI Morgan-Jones}

O cancro da haste foi detectado no Brasil, pela primeira vez, na safra 1989/90. Disseminou-se rapidamente a muitas regiões produtoras de soja e chegou a causar grandes perdas, devido à ocorrência de forma muito severa (Fig. 3 A).

No caso dessa doença, as Instituições de Pesquisa lançaram cultivares com resistência genética em poucos anos. Desde então, todas as cultivares de soja lançadas apresentam resistência ao patógeno $D$. phaseolorum $\mathrm{f}$. sp. meridionalis.

O patógeno $D$. phaseolorum f. sp. meridionalis é um fungo adaptado a regiões de temperatura mais elevada e encontrou no Brasil, país tropical, o ambiente favorável ao seu desenvolvimento.

O sintoma típico do cancro da haste pode ser observado na haste; inicia-se por um ponto necrótico pequeno, que evolui acima e abaixo desse ponto e atinge a medula, que se torna de coloração castanhoescura (Fig. 3 B). Como sintoma secundário, as folhas apresentam necrose entre as nervuras, conhecida como folha carijó (Fig. 3 C). Com a evolução da doença, a planta pode morrer.

O patógeno $D$. phaseolorum f. sp. meridionalis pode ser transmitido pela semente e sobrevive também em restos culturais (Fig. 3 D).

Como controle, recomenda-se o uso de cultivares resistentes, sementes certificadas e adubação potássica equilibrada, dentre outras medidas. 
Figura 3. Sintomas de cancro da haste em soja, causados por Diaporthe phaseolorum f. sp. meridionalis. A. Morte de plantas. B. Lesão na haste e escurecimento da medula. C. Folha carijó. D. Esporulação do fungo sobre a haste, nas duas formas de reprodução: anamórfica e pleomórfica, em restos culturais.
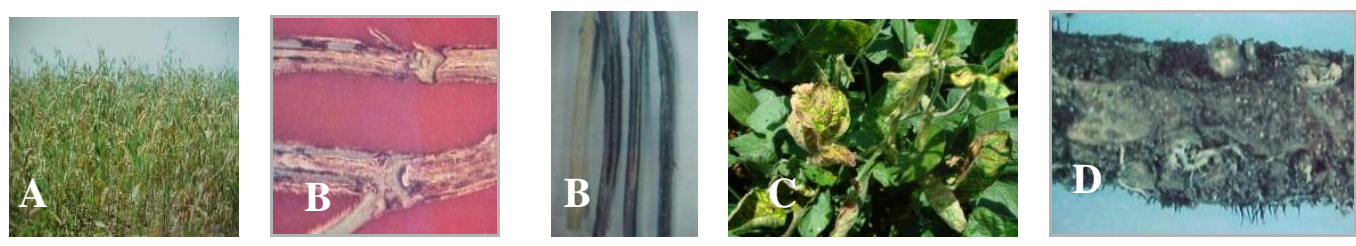

\subsubsection{Crestamento foliar e mancha púrpura da semente - Cercospora Kikuchii (T. Matsu. \& Tomoyasu) Gardner}

Essa doença é conhecida como doença de final de ciclo. É causada pelo fungo Cercospora Kikuchii, que se encontra amplamente disseminado nas regiões produtores de soja no Brasil. O desenvolvimento desse fungo é favorecido pela alta temperatura, entre $28^{\circ} \mathrm{C}$ a $30^{\circ} \mathrm{C}$ e alta umidade. $\mathrm{O}$ fungo pode causar sintomas em toda a parte aérea da planta (Fig. 4 A e B). Nas sementes, pode causar a mancha púrpura, que deprecia o produto, porém sementes sem essa mancha podem estar infectadas com o fungo (Fig. 4 C). A planta torna-se mais suscetível ao patógeno a partir do período do florescimento.

O fungo C. Kikuchii pode sobreviver na semente e nos restos culturais. Como medidas de controle são recomendadas uso de sementes sadias, adubação potássica equilibrada e quando necessário, o controle químico.

Encontram-se registrados 125 produtos no MAPA, para o controle de C. Kikuchii. Em <http://extranet.agricultura.gov.br/agrofit_cons/principal_agrofit_cons $>$ pode ser obtida a lista desses produtos.

Figura 4. Sintomas de crestamento foliar e mancha púrpura da semente em soja, causados por ercospora Kikuchii. A. Em folhas. B. Nas vagens. C. Nas sementes.
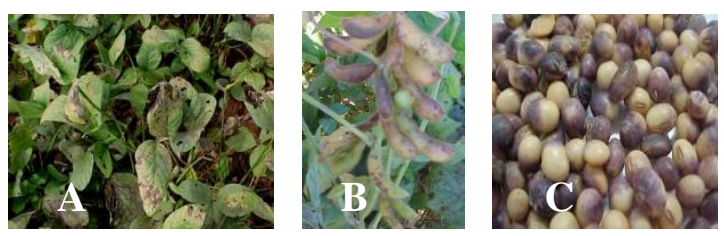

\subsubsection{Ferrugem asiática - Phakopsora pachyrhizi H. \& P. Sydow}

A ferrugem asiática, causada por Phakopsora pachyrhizi, foi descrita pela primeira vez no Brasil em 1979 em Minas Gerais, MG (Deslandes, 1979). Na safra 2000/01 foi constatado no Estado do Paraná (YORINORI et al., 2002) e a partir dessa safra a ferrugem atingiu rapidamente quase todas as regiões produtoras de soja, com perdas de até $80 \%$, nas primeiras safras. Os prejuízos foram parcialmente minimizados com o manejo integrado e uso de fungicidas.

As cultivares em uso, a maioria, não apresenta resistência ao fungo P. pachyrhizi. Apesar de lançadas cultivares com resistência, há necessidade de controle químico na maioria das safras e regiões produtoras de soja no Brasil. 
As condições para o desenvolvimento da ferrugem asiática são temperatura entre $8^{\circ} \mathrm{C}$ a $28^{\circ} \mathrm{C} \mathrm{e}$ alta umidade relativa. São necessários mais de seis horas de água livre na superfície do tecido da planta, para ocorrer a germinação dos uredosporos para posterior penetração, principalmente da folha. A temperatura ideal para esse processo é de $15^{\circ} \mathrm{C}$ a $25^{\circ} \mathrm{C}$. Após a penetração, ocorre a infecção e a temperatura ideal é de $20^{\circ} \mathrm{C}$ a $25^{\circ} \mathrm{C}$, cinco dias após, aparecem os sintomas iniciais e seis a sete dias após, inicia-se a liberação dos uredosporos.

Os sintomas da ferrugem podem ser confundidos com sintomas de outras doenças da cultura da soja, como crestamento bacteriano, pústula bacteriana e sintomas iniciais de mancha parda, assim, é necessária muita atenção no seu diagnóstico no início dos sintomas.

Os sintomas da ferrugem iniciam-se como um pequeno ponto, evolui para pústula ou urédia clara pequena, que cresce até o rompimento da película (Fig. $5 \mathrm{~A}$ ), quando se inicia a liberação dos uredosporos (Fig. 5 B). Após liberação dos uredosporos, ficam visíveis os poros por onde foram liberados os uredosporos, visíveis com lupa de 10 vezes a 20 vezes de aumento (Fig. 5 C). Conforme a severidade pode ocorrer desfolha prematura (Fig. 5 D) e comprometer a produção, pela má formação das vagens e grãos (Fig. 5 D).

Os uredosporos (Fig. 5 B) são disseminados pelos ventos, facilmente, a longas distâncias. O fungo P. pachyrhizi é um parasita obrigado, sobrevive em tecido vivo, porém há relatos de sobrevivência em restos culturais, por um período de até dois meses. $\mathrm{Na}$ entressafra esse fungo sobrevive em plantas voluntárias ou guaxas de soja e hospedeiros alternativos, que são mais de 95 espécies (Figs. 6 A, B e C).

Controle da ferrugem: apesar de mais de uma década de sua constatação no Brasil, causando dano econômico, continua causando prejuízos aos produtores e ao País, com a necessidade do controle químico. Apesar de cultivares com maiores níveis de resistência genética ao fungo Phakopsora pachyrhizi serem lançadas, é necessária complementação com fungicidas ao seu controle.

A partir da safra 2001/02 a ferrugem tem sido a principal doença da cultura no Brasil e o controle químico ainda é, no seu manejo integrado, o principal método de controle.

No início, a ferrugem foi eficientemente controlada com fungicidas do grupo dos triazóis, porém, com seu uso intensivo, houve o aumento da população do fungo $P$. pachyrhizi insensível ao fungicida, agravando-se o controle dessa doença nas principais regiões produtoras de soja.

Em safras posteriores, fungicidas do grupo das estrobilurinas foram recomendados para o controle da ferrugem em associações com fungicidas do grupo dos triazóis e outros grupos, o que têm proporcionado maior eficiência de controle e também, quando possível, os produtores se aliando ao uso de cultivares de soja com maior nível de resistência a $P$. pachyrhizi.

O controle da ferrugem exige muita atenção do produtor, desde a programação de plantio. É importante a escolha da cultivar adequada e a semeadura recomendada para a época e para a região, dando preferência a cultivares precoces e semeadura logo no início do período recomendado, para que a cultura se desenvolva livre ou com potencial de inóculo de P. pachyrhizi mais baixo. Semeaduras tardias podem sofrer maior deposição de uredosporos do fungo na planta, vindos de outros cultivos em estádios mais avançados e com incidência de ferrugem.

O monitoramento da cultura deve ser constante, para iniciar o controle químico no momento certo, desde a emergência e principalmente se o clima estiver favorável ao desenvolvimento da ferrugem, pois o patógeno é dependente de alta umidade e água na superfície do tecido da planta, por no mínimo seis horas de período de molhamento. Intensificar próximo ao estádio do florescimento e ou constatação da ferrugem na região. 
Constatados os sintomas iniciais, ou antes, dependendo das condições climáticas favoráveis e ocorrência de ferrugem na região, aplicar fungicidas recomendados. O controle químico deve ser preferencialmente de forma preventiva. Em

http://extranet.agricultura.gov.br/agrofit_cons/principal_agrofit_cons pode ser obtida a lista de fungicidas registrados no MAPA, são 103 fungicidas.

O número de aplicações dependerá de quando a ferrugem iniciar na cultura, reincidência da doença, outras doenças na cultura e avaliação do custo/benefício do tratamento.

Cuidados devem ser tomados quanto às aplicações dos fungicidas, pois há o problema de aparecimento de populações de P. pachyrhizi resistentes a fungicidas. Em ferrugens em geral, seus patógenos têm a característica de rápida multiplicação e em grande quantidade, o que propicia as mutações e/ou rápida multiplicação das populações não sensíveis, normalmente existentes, ao produto. Assim, é recomendado rotação de fungicidas de diferentes grupos de ação.

Vazio Sanitário: o Consórcio Antiferrugem instituiu a medida Vazio Sanitário, que foi adotado por muitos Estados brasileiros. O período instituído em cada Estado pode ser encontrado em http://www.consorcioantiferrugem.net

O objetivo do Vazio Sanitário é manter o período de entressafra sem plantas vivas de soja no campo, para reduzir o inóculo do fungo P. pachyrhizi. Esse período varia de 60 a 90 dias, de acordo com cada estado e 12 estados apresentam o período do vazio sanitário regulamentado. Essa medida tem retardado o início de epidemias e é importante que cada produtor de soja continue aplicando essa medida, rigorosamente, pois é fundamental para evitar maiores prejuízos devido à ferrugem.

Figura 5. Sintomas de ferrugem em soja, causadas por Pakopsora pachyrhizi. A. Pústulas jovens, e pústula quase no rompimento da película. B. início da liberação de uredosporos, plena esporulação e uredosporos. C. Urédias e poros após liberação dos uredosporos. D. Desfolha prematura e má formação de vagens.
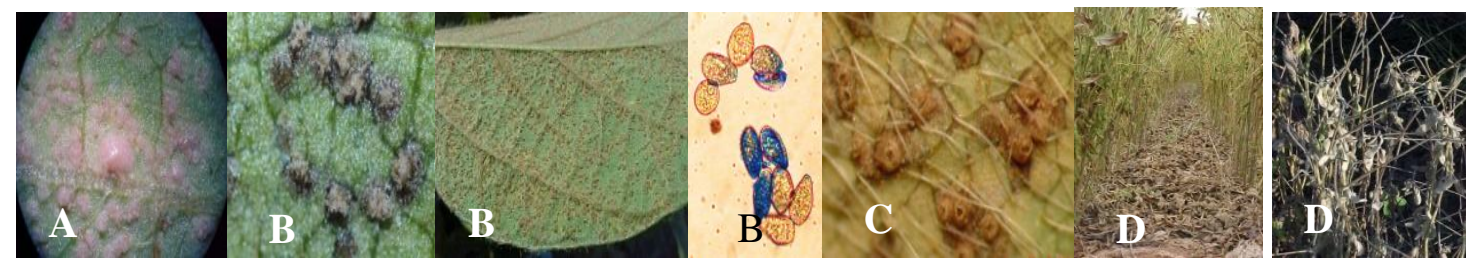

Figura 6. Sintomas de ferrugem em hospedeiros alternativos de Phakopsora pachyrhizi. A. Jacatupé. B. Desmodium. C. Cudzu comum.
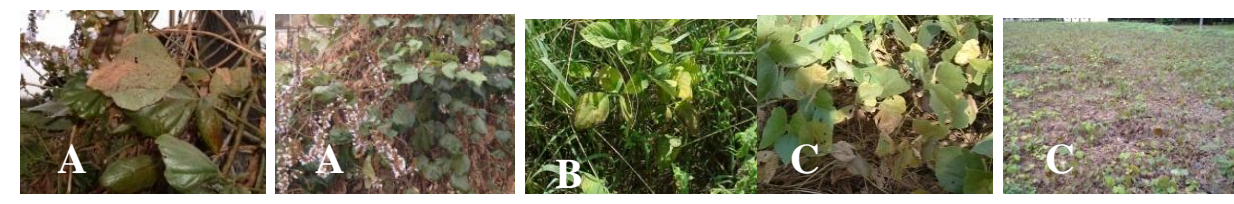


\subsubsection{Mancha alvo - Corynespora cassiicola (Berk. \& Curt.) Wei}

A doença mancha alvo é causada pelo fungo Corynespora cassiicola. O desenvolvimento desse fungo é favorecido pela temperatura entre $18^{\circ} \mathrm{C}$ a $21^{\circ} \mathrm{C}$ e alta umidade. Esse fungo pode causar doença também em plantas de algodão, abóbora, berinjela, feijão, caupi-feijão e mamona e vem aumentando sua incidência e severidade nas principais regiões produtoras de soja no Brasil. Algumas regiões vêm apresentando necessidade de controle químico. Encontram-se registrados 22 produtos no MAPA. Em http://extranet.agricultura.gov.br/agrofit_cons/principal_agrofit_cons pode ser obtida a lista desses produtos.

O sintoma típico da doença pode ser observado nas folhas (Fig. 7 A e B).

O fungo C. cassiicola sobrevive nos restos culturais e nas sementes, assim, é muito importante o uso de sementes certificadas.

Figura 7. Sintomas de mancha alvo em soja, causados por Corynespora cassicola. A. Em folhas. B. Sintoma típico, que dá o nome de mancha alvo.
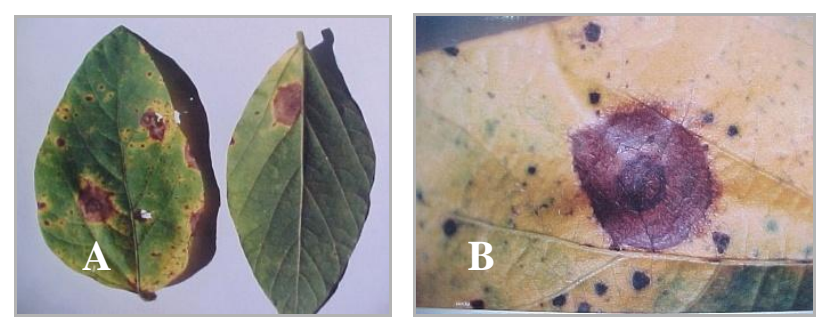

\subsubsection{Mancha olho-de-rã - Cercospora sojina Hara}

O desenvolvimento da doença mancha-olho-de-rã, causada pelo fungo Cercospora sojina, é favorecido em ambiente com temperatura entre $24^{\circ} \mathrm{C}$ a $28^{\circ} \mathrm{C}$ e alta umidade. O estádio favorável é a partir do início do florescimento. Pode causar danos consideráveis, pela desfolha prematura, que afeta a formação de vagens e sementes. O sintoma típico aparece nas folhas.

O fungo $C$. sojina apresenta variabilidade fisiológica. No Brasil, já foram constatadas algumas raças desse patógeno e a maioria dos cultivares de soja em uso apresenta resistência genética a essas raças.

Como o fungo $C$. sojina pode ser transmitido pelas sementes, pode introduzir uma nova raça numa região. Assim, é muito importante o uso de sementes sadias.

\subsubsection{Míldio - Peronospora manshurica (Naoum.) Syd. ex Gäum.}

Essa doença, causada pelo fungo Peronospora manshurica, é de ocorrência generalizada. Não tem apresentado, até o momento, grandes danos à cultura, o que não tem mostrado necessidade de controle químico, porém tem sido observado cultivos comerciais com maior severidade.

$\mathrm{O}$ desenvolvimento de $P$. manshurica é favorecido à temperatura entre $24^{\circ} \mathrm{C}$ a $28^{\circ} \mathrm{C}$ e alta umidade. O fungo pode causar sintomas em toda a parte aérea da planta e o sintoma típico pode ser observado nas folhas. Na parte superior, o fungo causa uma mancha verde clara e na parte inferior, sob alta umidade, forma-se o micélio do fungo e sua esporulação, semelhante à teia de aranha (Fig. 8 a e B). A semente pode ser afetada e apresentar rachaduras e estruturas do fungo, o que deprecia o produto. 
O fungo $P$. manchurica pode sobreviver na semente e nos restos culturais e como medidas de controle são recomendados uso de sementes sadias, eliminação de restos culturais, rotação de culturas e tratamento químico de sementes.

Figura 8. Sintomas de mildio em soja, causados por Peronospora manshurica. A. Na parte superior da folha a coloração é verde clara. B. Micélio do fungo e esporulação.
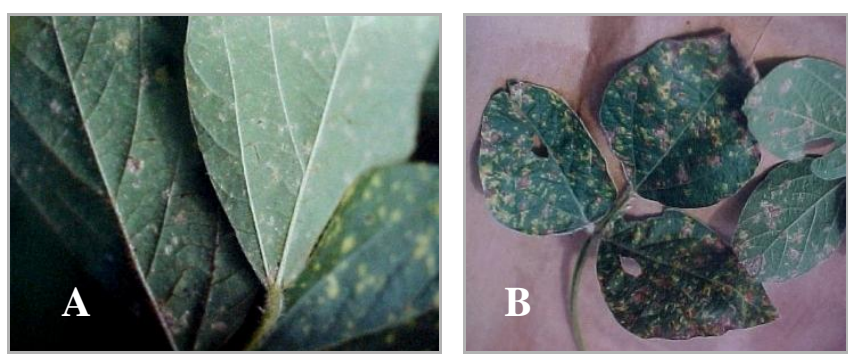

\subsubsection{Oídio - Microsphaera diffusa Cooke \& Peck}

A doença oídio, causada pelo fungo Microsphaera diffusa, era de ocorrência comum em plantas cultivadas em casa-de-vegetação, porém passou a ter importância econômica, com necessidade de controle químico em algumas safras e muitas regiões produtoras de soja. Pode ocorrer em qualquer estádio da cultura.

As condições favoráveis ao desenvolvimento do oídio são temperatura ao redor de $18^{\circ} \mathrm{C}$ e baixa umidade relativa. Pode desenvolver-se em toda parte aérea da planta e o sintoma típico é a coloração esbranquiçada com aspecto pulverulento sobre a superfície foliar, constituída de micélio e esporos do fungo (Fig. 9).

O fungo $M$. diffusa é um parasita obrigado, apresenta variabilidade fisiológica e forma estruturas de reprodução, os cleistotécios, que apresentam maior resistência às condições adversas. A grande quantidade de esporos formados na superfície foliar pode ser disseminada pelos ventos, facilmente.

Como medidas de controle são recomendadas o uso de cultivares com maior nível de resistência e controle químico. Encontram-se 98 produtos registrados no MAPA. Em http://extranet.agricultura.gov.br/agrofit cons/principal agrofit cons pode ser obtida a lista desses produtos.

Figura 9. Sintomas de oidio em soja, causados por Microsphaera diffusa.

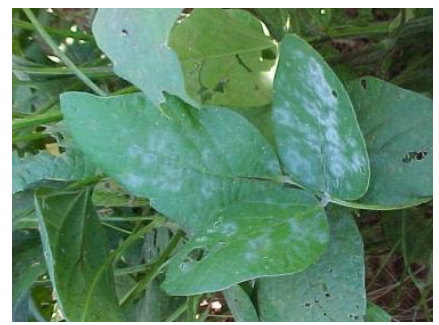




\subsubsection{Seca da vagem e da haste - Phomopsis phaseoli (Desm.) Sacc.}

Seca da vagem e da haste, causada pelo fungo Phomopsis phaseoli, é doença amplamente distribuída nas regiões produtoras de soja. Os maiores danos ocorrem se a colheita coincidir com chuvas frequentes. Nessas condições, as vagens podem se abrir e os grãos são deteriorados (Fig. 10 A).

$\mathrm{O}$ desenvolvimento da doença seca da vagem e da haste é favorecido à temperatura ao redor de $25^{\circ} \mathrm{C}$ e alta umidade relativa. Pode ocorrer em toda parte aérea da planta, porém raramente nas folhas. $\mathrm{O}$ sintoma típico é a formação linear de picnídios escuros ao longo da haste da planta (Fig. 10 B). As sementes infectadas podem apresentar micélio branco do fungo. $\mathrm{O}$ fungo $P$. phaseoli pode sobreviver e ser transmitido pelas sementes (Fig. $10 \mathrm{C}$ ), como também sobrevive em restos culturais e apresenta outras plantas hospedeiras.

Como medidas de controle são recomendadas uso de sementes sadias, cultivares resistentes, níveis adequados de potássio e tratamento de sementes com fungicidas.

Figura 10. Seca da vagem e da haste em soja, causada por Phomopsis phaseoli. A. Abertura da vagem com exposição da semente. B. Formação linear de picnídios escuros ao longo da haste. C. Phomopsis phaseoli em sementes.
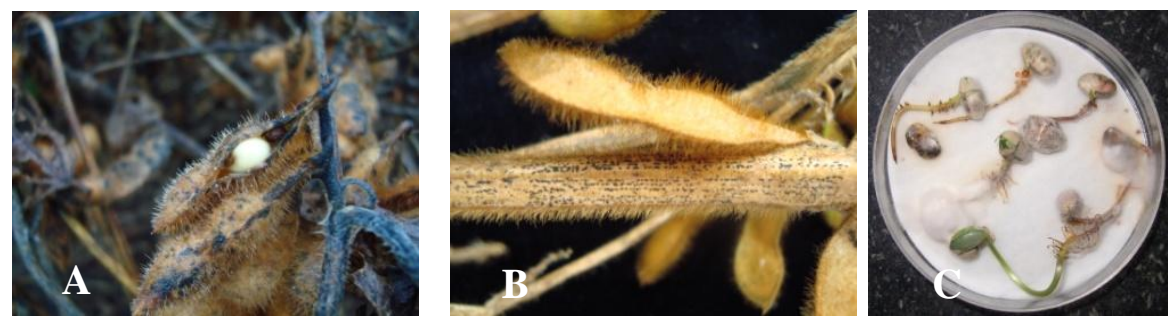

\subsubsection{Septoriose ou mancha-parda - Septoria glycines Hemmi}

Septoriose ou mancha-parda, causada pelo fungo Septoria glycines é denominada de doença de final de ciclo, porém pode ocorrer também no início da cultura, nas folhas baixeiras. É uma doença comum, de ocorrência frequente, com maior ou menor severidade.

As condições ideais ao desenvolvimento da septoriose são altas temperatura e umidade relativa. $\mathrm{O}$ sintoma característico são manchas necróticas com halo amarelo, nas folhas (Fig. 11 A). Pode causar desfolha prematura e má formação das vagens, com prejuízos na produção (Fig. 11 B).

$\mathrm{O}$ fungo pode sobreviver nas sementes e nos restos culturais.

Como medidas de controle são recomendadas uso de sementes sadias, rotação de culturas e controle químico. Encontram-se 106 produtos registrados no MAPA. Em http://extranet.agricultura.gov.br/agrofit_cons/principal_agrofit_cons pode ser obtida a lista desses produtos.

Figura 11. Septoriose ou mancha-parda em soja, causada por Septoria glycines. A. Manchas necróticas com halo amarelo. B. Desfolha prematura e má formação das vagens.
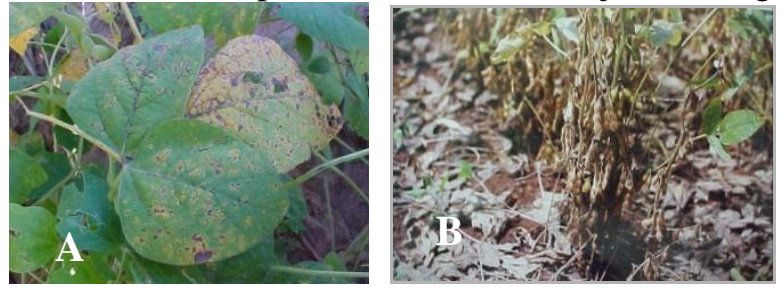
Tabela 2. Principais doenças (patógeno causador) fúngicas da parte aérea da cultura da soja, agentes de disseminação, condições favoráveis e forma de sobrevivência.

\begin{tabular}{|c|c|c|c|}
\hline Doença & $\begin{array}{l}\text { Agentes de } \\
\text { disseminação }\end{array}$ & Condições favoráveis & $\begin{array}{l}\text { Sobrevivência do } \\
\text { patógeno }\end{array}$ \\
\hline $\begin{array}{l}\text { Antracnose } \\
\text { (Colletotrichum } \\
\text { truncatum) } \\
\text { Cancro da haste } \\
\text { (Diaporthe } \\
\text { phaseolorum f. sp. } \\
\text { meridionalis) }\end{array}$ & $\begin{array}{l}\text { Vento, chuva, insetos, } \\
\text { sementes e } \\
\text { implementos agrícolas } \\
\text { Vento, chuva, insetos, } \\
\text { animais, implementos } \\
\text { agrícolas e sementes }\end{array}$ & $\begin{array}{l}\text { Temperatura entre } \\
28^{\circ} \mathrm{C} \text { a } 34^{\circ} \mathrm{C} \\
\text { Alta umidade } \\
\text { Alta temperatura } \\
\text { Alta umidade }\end{array}$ & $\begin{array}{l}\text { Sementes e restos de } \\
\text { cultura }\end{array}$ \\
\hline $\begin{array}{l}\text { Crestamento foliar e } \\
\text { mancha púrpura da } \\
\text { semente (Cercospora } \\
\text { Kikuchii) }\end{array}$ & $\begin{array}{l}\text { Vento, insetos, } \\
\text { implementos agrícolas, } \\
\text { animais e sementes }\end{array}$ & $\begin{array}{l}\text { Temperatura entre } \\
28^{\circ} \mathrm{C} \text { a } 30^{\circ} \mathrm{C} \\
\text { Alta umidade }\end{array}$ & $\begin{array}{l}\text { Restos de cultura e } \\
\text { sementes }\end{array}$ \\
\hline Ferrugem asiática & Vento & $\begin{array}{l}\text { Temperatura entre } \\
18^{\circ} \mathrm{C} \text { a } 28^{\circ} \mathrm{C} \\
\text { Alta umidade relativa }\end{array}$ & Restos de cultura \\
\hline $\begin{array}{l}\text { Mancha alvo } \\
\text { (Corynespora } \\
\text { cassiicola) }\end{array}$ & Vento, chuva e insetos & $\begin{array}{l}\text { Temperatura moderada, } \\
\text { entre } \\
18^{\circ} \mathrm{C} \text { a } 21^{\circ} \mathrm{Ce} \\
\text { Alta umidade relativa }\end{array}$ & $\begin{array}{l}\text { Restos de cultura, } \\
\text { sementes e outras } \\
\text { espécies de plantas, } \\
\text { como algodão, abóbora, } \\
\text { berinjela, caupi, feijão e } \\
\text { mamona }\end{array}$ \\
\hline $\begin{array}{l}\text { Míldio (Peronospora } \\
\text { manshurica) }\end{array}$ & $\begin{array}{l}\text { Vento, insetos, chuva, } \\
\text { animais e sementes }\end{array}$ & $\begin{array}{l}\text { Temperatura entre } \\
24^{\circ} \mathrm{C} \text { a } 28^{\circ} \mathrm{C} \\
\text { Alta umidade }\end{array}$ & $\begin{array}{l}\text { Sementes e restos } \\
\text { culturais }\end{array}$ \\
\hline $\begin{array}{l}\text { Oídio (Microsphaera } \\
\text { diffusa) }\end{array}$ & $\begin{array}{l}\text { Vento, insetos, chuva e } \\
\text { animais }\end{array}$ & $\begin{array}{l}\text { Temperatura ao redor } \\
\text { de } 18^{\circ} \mathrm{C} \\
\text { Baixa umidade relativa }\end{array}$ & $\begin{array}{l}\text { Sementes e restos } \\
\text { culturais }\end{array}$ \\
\hline $\begin{array}{l}\text { Seca da vagem e da } \\
\text { haste (Phomopsis } \\
\text { phaseoli) }\end{array}$ & $\begin{array}{l}\text { Sementes, chuva } \\
\text { acompanhada de vento } \\
\text { e implementos } \\
\text { agrícolas }\end{array}$ & $\begin{array}{l}\text { Temperatura ao redor } \\
\text { de } 25^{\circ} \mathrm{C} \\
\text { Alta umidade relativa }\end{array}$ & $\begin{array}{l}\text { Sementes e restos de } \\
\text { cultura e outras plantas } \\
\text { hospedeiras }\end{array}$ \\
\hline $\begin{array}{l}\text { Septoriose ou mancha- } \\
\text { parda (Septoria } \\
\text { glycines) }\end{array}$ & $\begin{array}{l}\text { Sementes, restos de } \\
\text { cultura de feijoeiro, } \\
\text { milho e sorgo } \\
\text { infectados }\end{array}$ & $\begin{array}{l}\text { Alta temperatura } \\
\text { Alta umidade relativa }\end{array}$ & $\begin{array}{l}\text { Sementes e restos } \\
\text { culturais }\end{array}$ \\
\hline
\end{tabular}

Compilado segundo Sinclair, 1982; ITO, 2005.

\subsection{Doenças causadas por fungos habitantes do solo}

As doenças causadas por fungos de solo são de difícil controle, além de quase não se encontrar material comercial de soja com resistência aos patógenos causadores dessas doenças (Tabela 3).

\subsubsection{Mofo branco - Sclerotinia sclerotiorum (Lib.) de Bary}

O fungo Sclerotinia sclerotiorum é cosmopolita e polífago, apresenta mais de 400 espécies de plantas hospedeiras. 
A doença mofo branco, causada pelo fungo S. sclerotiorum, vem ocorrendo de forma severa e em alta incidência em muitas regiões produtoras, ultimamente, com o aumento do potencial de inóculo do fungo no solo. As cultivares de soja em exploração comercial não tem apresentado resistência ao patógeno, que, uma vez introduzido na área, é de difícil controle, pois além de produzir estruturas de resistência, apresenta ampla gama de hospedeiros, incluindo-se algumas plantas daninhas.

A doença mofo branco apresenta maior importância em regiões de clima temperado ou regiões tropicais em épocas frias com alta umidade relativa.

O desenvolvimento do mofo branco é favorecido em condições de baixa temperatura, entre $16^{\circ} \mathrm{C}$ a $22^{\circ} \mathrm{C}$ e alta umidade. A fase propícia é quando a cultura atinge a fase do florescimento.

Os sintomas característicos são murcha e seca das folhas, podridão aquosa da haste, verde-claras no início e castanho-avermelhadas, posteriormente. Toda a parte aérea da planta pode ser afetada (Foto 12 A). Sob a parte afetada, podem desenvolver micélio branco e estruturas de resistência, os escleródios brancos no início e negros ao final de sua formação (Foto $12 \mathrm{~B}$ ). Esses escleródios podem ser formados até no interior das hastes e vagens (Foto $12 \mathrm{C}$ ).

O fungo pode sobreviver nas sementes, nos restos culturais e no solo. As estruturas de resistência, os escleródios podem sobreviver no solo por muitos anos e podem também ser disseminados misturados às sementes, por contaminação concomitante e apresentam tamanhos e formas variados (Foto 12 D).

Controle do mofo branco: o controle da doença mofo branco é complexo, pois o fungo $S$. sclerotiorum apresenta duas formas de ataque às plantas, por via aérea, pelos ascosporos e via solo pelos escleródios, que germinam e iniciam o processo do seu ciclo de vida. Assim, para seu controle, deve ser realizado o manejo integrado, incluindo-se fungicidas em muitas situações.

- Uso de sementes certificadas

- Tratamento de sementes

- Rotação de culturas: gramíneas

- Controle de plantas daninhas hospedeiras de S. sclerotiorum, como amendoim bravo, corda-de-viola, guanxuma, mentrasto, picão preto e serralha

- Escolha da cultivar: porte ereto

- Escolha da época e evitar plantios adensados

- Cobertura do solo com palha

- Enterrar os escleródios: $20 \mathrm{~cm}$ a $30 \mathrm{~cm}$

- Plantio direto: escleródios eliminados por bactérias e fungos = microrganismos benéficos

- Evitar adubações excessivas com nitrogênio

- Controle biológico

- Controle químico: trabalhos têm mostrado eficiência de fungicidas no controle do mofo branco em soja, com acréscimo na produtividade (MEYER et al., 2011)

Em http://extranet.agricultura.gov.br/agrofit cons/principal agrofit cons pode ser obtida a lista de produtos registrados no MAPA, para o controle da ferrugem; são 18 produtos. 
Figura 12. Mofo branco em soja, doença causada por Sclerotinia sclerotiorum. A. Murcha e seca das folhas. B. Micélio branco e formação de escleródios do fungo. C. formação de escleródios no interior da haste. D. Escleródios em contaminação concomitante às sementes, tamanhos e formas variados.
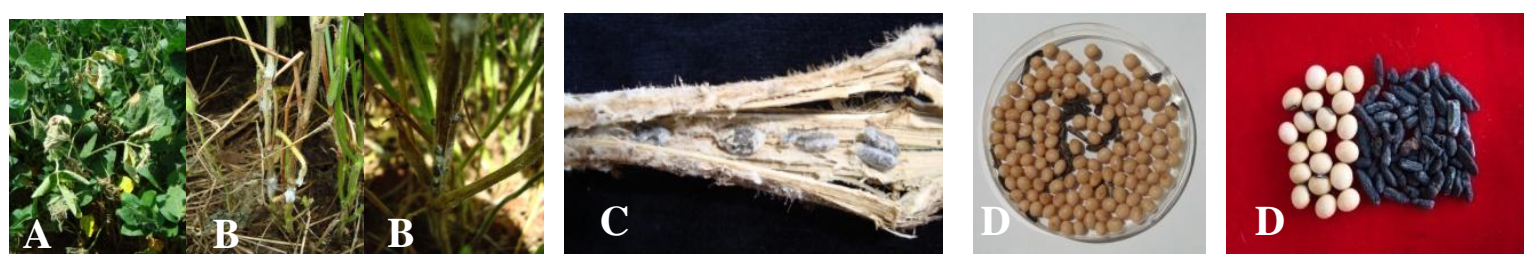

\subsubsection{Morte por fusarium - Fusarium spp.}

A doença morte por fusarium pode ser causada por muitas espécies do fungo do gênero Fusarium. A doença pode ocorrer na fase inicial da cultura e na fase da reprodução.

As condições ideais são temperatura entre $20^{\circ} \mathrm{C}$ e $28^{\circ} \mathrm{C}$, alta umidade do solo, solo compactado e com pH abaixo de 6. Com o progresso da doença, as plantas apresentam amarelecimento das folhas e podem evoluir até a sua morte (Fig. $13 \mathrm{~A}$ ). Em alta umidade, forma-se micélio branco sobre a haste onde são formados os clamidosporos, estruturas de resistência.

Fusarium spp. podem sobreviver nas sementes e nos restos culturais (Fig. 13 B e C). Para o controle são recomendados o uso de sementes sadias, tratamento de sementes, incorporação de restos culturais e rotação de culturas.

Para o controle de $F$. oxysporum é recomendado o fungicida tiofanato metílico na dose de 100 $\mathrm{mL} / 100 \mathrm{Kg}$ de sementes a $150 \mathrm{~mL} / 100 \mathrm{Kg}$ de sementes.

Figura 13. Morte por fusarium em soja, causada por Fusarium spp. A. Morte de plantas. B. Sobrevivência de Fusarium spp. em restos culturais. C. Sobrevivência de Fusarium spp. em sementes.
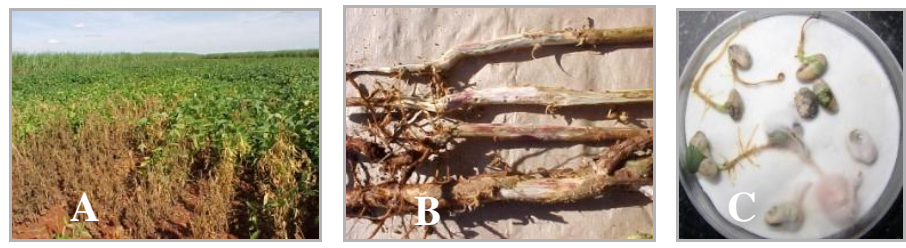

\subsubsection{Podridão cinzenta - Macrophomina phaseolina (Tassi) Goid.}

O patógeno Macrophomina phaseolina encontra-se amplamente disseminado, é polífago, pode ser patogênico a centenas de espécies de plantas e produz estruturas de resistência, que confere sobrevivência no solo por muito tempo.

O desenvolvimento da podridão cinzenta é favorecido em condições de estresse hídrico e alta temperatura, entre $28^{\circ} \mathrm{C}$ a $35^{\circ} \mathrm{C}$; a severidade pode ser maior em solo compactado. A doença não se manifesta em baixa temperatura.

Os sintomas característicos são a podridão das raízes e da haste acima do solo (Fig. 14 A). Com o progresso da doença, são formadas as estruturas de reprodução do fungo na haste e as estruturas de 
resistência, os microescleródios, que dão a coloração cinza na haste (Fig. 14 B). Como sintoma secundário, aparece necrose entre as nervuras nas folhas, conhecida como folha carijó (Fig. 14 C). Em alta severidade, pode ocorrer desfolha prematura e má formação das vagens e até a morte da planta, com prejuízos na produção (Fig. 14 D).

O fungo pode sobreviver nas sementes e nos restos culturais e no solo. As estruturas de resistência, os microescleródios podem sobreviver no solo por muitos anos (Fig. $14 \mathrm{E}$ ).

Como medida de controle é recomendada uso de sementes sadias. A rotação de culturas pode não proporcionar benefícios almejados, pois o patógeno apresenta muitas plantas hospedeiras.

Figura 14. Sintomas de podridão cinzenta em soja, causados por Macrophomina phaseolina. A. Podridão das raízes e da haste acima do solo. B. Microescleródios que dão a coloração cinza na haste. C. Necrose entre as nervuras da folha, conhecida como folha carijó. D. Morte das plantas. E. Sobrevivência de M. phaseolina em restos culturais e no solo.
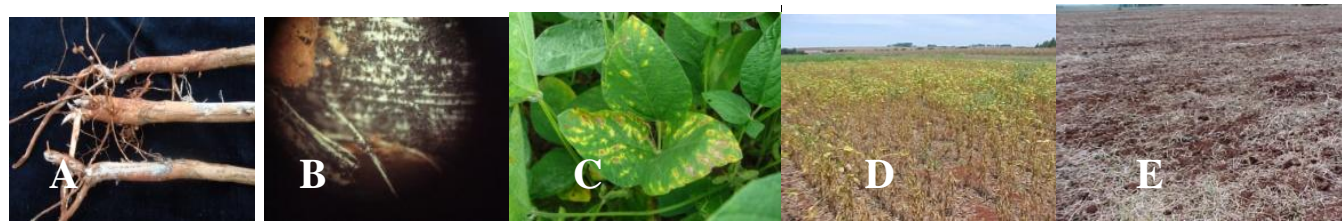

\subsubsection{Podridão parda da haste - Phialophora gregata}

Essa doença ocorre em regiões de temperatura amena, ao redor de $16^{\circ} \mathrm{C}$ a $18^{\circ} \mathrm{C}$. O desenvolvimento da doença é mais rápido em plantas mais velhas, sendo favorecido pelo cultivo intensivo.

O sintoma da doença manifesta-se mais no estádio reprodutivo da planta. Pode ser observado sintoma de folha carijó e também o escurecimento da medula e do sistema vascular (Fig. 15 A e B).

O patógeno $P$. gregata pode ser transmitido pela semente, sobrevive no solo, em restos culturais e os esporos podem sobreviver a uma profundidade de até $30 \mathrm{~cm}$.

Figura 15. Sintomas de podridão parda da haste em soja, causados por Phialophora gregata. A. folha carijó. B. Escurecimento da medula e do sistema vascular.
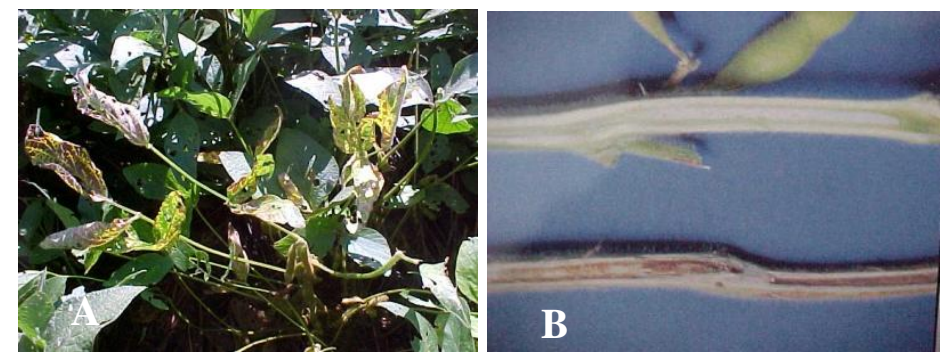

\subsubsection{Rizoctoniose, tombamento de plântulas e morte em reboleiras - Rhizoctonia solani Kuehn}

Essa doença, causada pelo fungo Rhizoctonia solani, pode ocorrer em qualquer estádio da cultura. As condições favoráveis ao desenvolvimento da doença são períodos chuvosos e frios. A compactação do solo propicia a doença e o fungo pode causar tombamento e morte das plântulas. Em estádio mais 
avançado, pode causar a morte da planta afetando todo o sistema radicular.

O patógeno $R$. solani sobrevive em sementes, restos culturais, no solo em forma de escleródios (Fig. 16), em hospedeiros alternativos e na rizosfera de plantas.

Como medidas de controle são recomendadas o uso de sementes sadias, rotação de culturas, controle biológico, tratamento de sementes com fungicidas e semeadura em menor profundidade em época fria e com chuvas.

Em http://extranet.agricultura.gov.br/agrofit cons/principal agrofit cons pode ser obtida a lista de 30 produtos registrados no MAPA, para o controle de $R$. solani.

Figura 16. Formação de escleródios de Rhizoctonia solani, em meio de cultura.

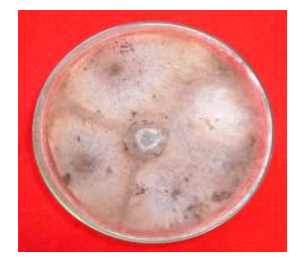

\subsubsection{Tombamento e murcha de sclerotium - Sclerotium rolfsii Sacc.}

O fungo Sclerotium rolfsii encontra-se amplamente disseminado e apresenta maior importância em países tropicais e subtropicais.

A doença pode ocorrer na fase inicial da cultura e na fase reprodutiva, no entanto, a doença pode ser observada em qualquer fase da cultura. As condições ideais são alta temperatura, entre $25^{\circ} \mathrm{C} \mathrm{e} 35^{\circ} \mathrm{C}$, alta umidade do solo, solo compactado e com baixo $\mathrm{pH}$.

Com o progresso da doença, as plantas apresentam, como sintoma secundário, folhas com necrose entre nervuras, conhecidas como folhas carijós e podem evoluir até a morte. Com alta umidade, forma-se micélio branco vigoroso, onde são formados os escleródios, brancos no início e que evoluem à coloração castanha e tornam-se semelhantes a sementes de mostarda (Fig. 17 A e B).

O fungo $S$. rolfsii pode causar o tombamento de pré e pós- emergência, com podridão mole no colo e sistema radicular. Solo infestado com nematóides do gênero Meloidogyne pode agravar a doença, pois os nematóides provocam ferimentos nas raízes, abrindo porta de entrada ao fungo.

Sclerotium rolfsii pode sobreviver nas sementes, nos restos culturais, no solo por muitos anos, em forma de escleródios e afeta mais de 200 espécies de plantas.

Para o controle é recomendado o uso de sementes sadias, rotação com gramíneas, incorporação dos restos culturais e tratamento de sementes com carboxina + thiram (vitavax-thiram) na dose de $200 \mathrm{~g}$ do produto comercial/100 $\mathrm{kg}$ de sementes.

Figura 17. Sintomas de murcha de sclerotium em soja, causados por Sclerotium rolfsii. A. Plantas mortas, com formação de micélio branco do fungo. B. Micélio branco vigoroso e formação de escleródios.
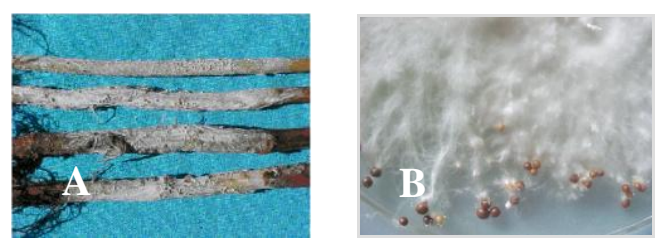
Tabela 3. Principais doenças (patógeno causador) da cultura da soja, causadas por fungos habitantes do solo, agentes de disseminação, condições favoráveis e forma de sobrevivência.

\begin{tabular}{|c|c|c|c|}
\hline Doença & $\begin{array}{l}\text { Agentes de } \\
\text { disseminação }\end{array}$ & Condições favoráveis & Sobrevivência do patógeno \\
\hline $\begin{array}{l}\text { Mofo branco } \\
\text { (Sclerotinia } \\
\text { sclerotiorum) }\end{array}$ & $\begin{array}{l}\text { Vento, chuva, } \\
\text { sementes, animais, } \\
\text { implementos agrícola }\end{array}$ & $\begin{array}{l}\text { Temperatura entre } \\
16^{\circ} \mathrm{C} \text { a } 22^{\circ} \mathrm{C} \\
\text { Alta umidade } \\
\text { Solo compactado } \\
\text { Presença de nematóides- } \\
\text { Meloidogyne }\end{array}$ & $\begin{array}{l}\text { Sementes, restos culturais, } \\
\text { escleródios e mais de } 400 \\
\text { espécies de plantas } \\
\text { hospedeiras }\end{array}$ \\
\hline $\begin{array}{l}\text { Morte por fusarium } \\
\text { (Fusarium spp.) }\end{array}$ & $\begin{array}{l}\text { Vento, chuva, } \\
\text { sementes, animais, } \\
\text { implementos agrícola }\end{array}$ & $\begin{array}{l}\text { Temperatura entre } \\
20^{\circ} \mathrm{C} \text { a } 28^{\circ} \mathrm{C} \\
\text { Alta umidade } \\
\text { Solo compactado }\end{array}$ & $\begin{array}{l}\text { Sementes e restos } \\
\text { de cultura }\end{array}$ \\
\hline $\begin{array}{l}\text { Podridão cinzenta } \\
\text { do caule } \\
\text { (Macrophomina } \\
\text { phaseolina) }\end{array}$ & $\begin{array}{l}\text { Sementes, } \\
\text { escleródios, } \\
\text { implementos agrícolas }\end{array}$ & $\begin{array}{l}\text { Temperatura alta, entre } \\
28^{\circ} \mathrm{C} \text { a } 35^{\circ} \mathrm{C} \\
\text { stress hídrico } \\
\text { Solo compactado }\end{array}$ & $\begin{array}{l}\text { Sementes, restos culturais, } \\
\text { escleródios, ampla gama } \\
\text { de hospedeiros }\end{array}$ \\
\hline $\begin{array}{l}\text { Podridão parda da } \\
\text { haste (Phialophora } \\
\text { gregata) }\end{array}$ & $\begin{array}{l}\text { Àgua de irrigação, } \\
\text { animais, sementes }\end{array}$ & $\begin{array}{l}\text { Temperatura entre } \\
16^{\circ} \mathrm{C} \text { a } 18^{\circ} \mathrm{C} \\
\text { Alta umidade }\end{array}$ & $\begin{array}{l}\text { Sementes, restos culturais. } \\
\text { Os esporos sobrevivem a } \\
30 \mathrm{~cm} \text { de profundidade do } \\
\text { solo }\end{array}$ \\
\hline $\begin{array}{l}\text { Rizoctoniose, } \\
\text { tombamento de } \\
\text { plântulas e morte } \\
\text { em reboleiras } \\
\text { (Rhizoctonia } \\
\text { solani) }\end{array}$ & $\begin{array}{l}\text { Vento, chuva, } \\
\text { sementes, animais, } \\
\text { implementos agrícolas }\end{array}$ & $\begin{array}{l}\text { Baixa temperatura alta e } \\
\text { alta umidade do solo }\end{array}$ & $\begin{array}{l}\text { Sementes, escleródios, } \\
\text { restos de cultura, ampla } \\
\text { gama de hospedeiros e } \\
\text { rizosfera de plantas }\end{array}$ \\
\hline $\begin{array}{l}\text { Tombamento e } \\
\text { murcha de } \\
\text { sclerotium } \\
\text { (Sclerotium rolfsii) }\end{array}$ & $\begin{array}{l}\text { Vento, chuva, } \\
\text { sementes, animais, } \\
\text { implementos agrícola }\end{array}$ & $\begin{array}{l}\text { Temperatura entre } \\
25^{\circ} \mathrm{C} \text { a } 35^{\circ} \mathrm{C} \\
\text { Alta umidade } \\
\text { Solo compactado, baixo } \\
\text { pH e presença de } \\
\text { nematóides-Meloidogyne }\end{array}$ & $\begin{array}{l}\text { Sementes, restos culturais, } \\
\text { escleródios e cerca de } 200 \\
\text { espécies de plantas }\end{array}$ \\
\hline
\end{tabular}

Compilado segundo Sinclair, 1982; ITO, 2005.

\section{Fungos em sementes soja}

Quase todos os patógenos da cultura da soja são transmitidos e/ou transportados pelas sementes. Os patógenos podem infectar as sementes durante a sua formação, no campo, nas operações de colheita, transporte e beneficiamento e durante o armazenamento.

A chuva durante o período da colheita de soja favorece a infecção das sementes pelos patógenos e resulta em sementes de baixa qualidade sanitária.

Os principais fungos em sementes de soja são: Alternaria spp., Aspergillus spp., Cercospora Kikuchii, Cercospora sojina, Cladosporium spp., Colletotrichum truncatum, Corynespora cassiicola, Fusarium spp., F. oxysporum, F. semitectum, Macrophomina phaseolina, Penicillium spp., Peronospora manchurica, Phialophora gregata, Phompsis spp., Rhizoctonia solani, Rhizopus spp., Sclerotinia sclerotiorum e Sclerotium rolfsii (Fig. 18 A).

Os fungos Aspergillus spp., Penicillium spp. e Rhizopus spp. são denominados de fungos de armazenamento (Fig. $18 \mathrm{~B}$ ). A alta umidade nas sementes no armazenamento aumenta a porcentagem 
desses fungos, assim a umidade das sementes deve estar ao redor de $12 \%$ a $13 \%$ ao se acondicionar no armazém. Deve-se também manter baixa a umidade do ambiente.

Figura 18. Fungos em sementes de soja. A. Patógenos de campo: 1. Sclerotinia sclerotiorum. 2. Cercospora Kikuchii. 3. Fusarium sp. 4. Phomopsis phaseoli. B. Fungos de armazenamento: 1. Aspergillus niger. 2. Aspergillus sp. e Penicillium sp. 3. Rhizopus sp.
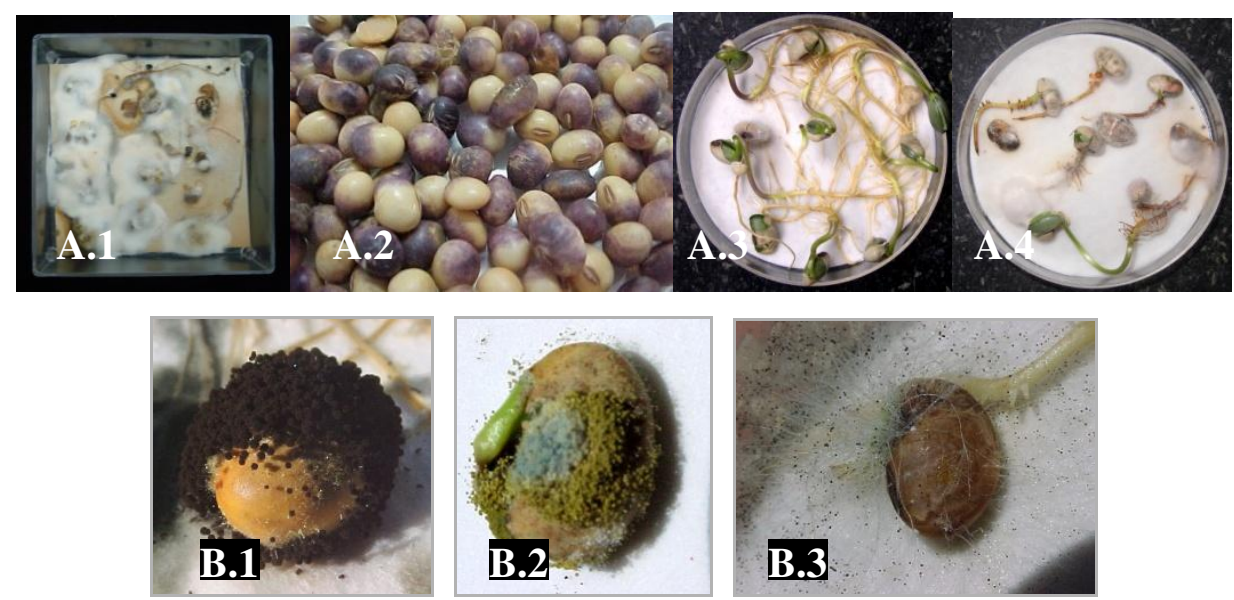

\section{Tratamento químico de sementes}

As sementes são importante veículo de introdução de patógenos a áreas onde ainda não ocorrem e também disseminam patógenos a curta e longas distâncias, além de mantê-los viáveis por muitos anos.

O tratamento de sementes de soja com fungicidas é prática de baixo custo e evita a introdução e a disseminação de patógenos, proporciona a proteção contra patógenos presentes no solo, assegura a emergência em condições adversas de ambiente, com uniformidade do estande inicial.

Muitos fungicidas encontram-se registrados ao tratamento de sementes soja no www.agrofit.agricultura.gov.br.

\section{Manejo integrado de doenças}

A ocorrência de doenças em soja e sua maior severidade dependem de fatores como clima, cultivares, potencial de inóculo de patógenos, estrutura e fertilidade do solo, vigor da planta, dentre outros.

$\mathrm{Na}$ implantação da cultura de soja, é importante adquirir sementes de boa qualidade, certificadas e de preferência com resistência genética a patógenos, de acordo com a sua disponibilidade.

A atenção com o solo é outro fator muito importante. Recomenda-se fazer a sua análise e correção da acidez, de acordo com o resultado, para que a planta de soja aproveite a adubação com maior eficiência. Assim, a calagem e adubação adequadas e níveis adequados de potássio podem proporcionar maior vigor às plantas e, ao ataque por patógenos, podem manifestar sua resistência e sofrer menos, apresentar menor severidade da doença.

A rotação de culturas, incluindo-se a adubação verde pode reduzir o potencial de inóculo de patógenos no solo, além de melhorar a estrutura do solo, reduzir a compactação, enriquecer a diversidade microbiológica, aumentar os organismos benéficos à cultura, proporcionando maior proteção contra os patógenos. 
A escolha da cultivar adequada e a semeadura recomendada para a época e para a região é importante para que a planta consiga produzir de forma a atingir seu potencial genético.

O espaçamento adequado, conforme a época, cultivar e histórico da área podem evitar maiores danos por patógenos.

Em cultivos irrigados, é importante o manejo da água de irrigação, para evitar ataques, principalmente de fungos de solo, incluindo-se Sclerotinia sclerotiorum.

Com o aumento da incidência e severidade da doença mofo branco, o uso de controle biológico vem se tornando mais frequente. Ao adquirir o produto comercial, deve-se tomar cuidado com sua qualidade e com sua forma de aplicação; seguir atentamente as recomendações do fabricante.

O controle químico deve ser utilizado como última alternativa, após emprego de todas as inovações tecnológicas disponíveis para formação de boa cultura de soja. Doenças como oídio, doenças de final de ciclo (DFC), ferrugem, mancha alvo e mofo branco têm sido controladas com fungicidas.

Para o controle químico das doenças/patógenos, no site do MAPA podem ser encontrados todos os produtos recomendados à cultura: www.agrofit.agricultura.gov.br

\section{REFERÊNCIAS}

CAVAlCANTI, A.B.U. Relatório do campo de ensaio. Boletim da Estação Agronômica de Campinas, Campinas, v.3, n.2, 1892.

CONSÓRCIO ANTIFERRUGEM, 2009. Dados reais. Disponível em: http://www.consorcioantiferrugem.net. Acesso em 04 mar. 2011.

DAFFERT, F.W. Relatório Anual do Instituto Agronômico do Estado de São Paulo. Campinas: Instituto Agronômico, 1892. 26p.

DESLANDES, J. A. Ferrugem da soja e de outras leguminosas causada por Phakopsora pachyrizi no Estado de Minas Gerais. Fitopatologia Brasileira, Brasília, DF, v.4, p.337-339, 1979.

D'UTRA, G.R.P. Cultura do feijão chinez. Boletim do Instituto Agronômico, Campinas, v.10, n.3, p.131-139, 1899 a.

D'UTRA, G.R.P. Nova cultura experimental de soja. Boletim do Instituto Agronômico, Campinas, v.10, n.9/10, p.682-687, 1899 b.

EMBRAPA. Doenças e medidas de controle. In: Tecnologias de produção de soja - região central do Brasil 2012 e 2013. - Londrina: Embrapa Soja, 2011. 261 p. Sistemas de Produção / Embrapa Soja, ISSN 2176-2902; n.15,p.197-250. 2011.

FERREIRA, L.P.; LEHMAN, P.S.; ALMEIDA, A.M.R. Doenças da soja no Brasil. Londrina, EMBRAPA/CNPSo, 1979. 41 p. (Circular Técnica, 01).

MASCARENHAS, H.A.A.; MIRANDA, M.A.C. de; TISSELLI FILHO, O. Contribuição do Instituto Agronômico na evolução da cultura da soja no Estado de São Paulo. Campinas: Instituto Agronômico, 1974. 22p. (Circular, 32).

ITO, M.F. Resistência e manejo das principais doenças da cultura da soja. In: Manejo integrado de doenças de grandes culturas - algodão, soja e café. In: SIMPÓSIO DE CONTROLE DE DOENÇAS DE PLANTAS, 5. 22 a 24 de Novembro/2005. UFLA, Lavras, MG. Palestras... Soja: 1-19. 2005. CDROOM. 
MEYER, M. C.; NUNES JUNIOR, J.; PIMENTA, C.B.; SEII, A.H.; NUNES SOBRINHO, J.B.; COSTA, N.B.; GUARNIERI, S.F.. Eficiência de fungicidas no controle de mofo branco (Sclerotinia sclerotiorum) em soja, no Estado de Goiás. In:REUNIÃO DE PESQUISA DE SOJA DA REGIÃO CENTRAL DO BRASIL,32. 2011, São Pedro, SP.REUNIÃO DE PESQUISA DE SOJA DA REGIÃO CENTRAL DO BRASIL, 32. Resumos... Londrina : Embrapa Soja, 2011. p. 148-150.

SECRETARIA DA AGRICULTURA, COMÉRCIO \& OBRAS PÚBLICAS DO ESTADO DE SÃO PAULO. Boletim da Agricultura, São Paulo, $1^{\text {a }}$ série, n.1, p.88, 1900.

SECRETARIA DA AGRICULTURA, COMÉRCIO \& OBRAS PÚBLICAS DO ESTADO DE SÃO PAULO. Boletim da Agricultura, São Paulo, 2ª série, p.48, 1901.

SINCLAIR, J.B. (ed.). Compendium of Soybean Diseases. 2. Ed. St. Paul. The American Phytopathological Society, 1982. 104 p.

YORINORI, J.T.; PAIVA, W.M.; FREDERICK, R.D.; FERNANDEZ, P.F.T. Ferrugem da soja (Phakopsora pachyrhizi) no Brasil e no Paraguai, nas safras 2000/01 e 2001/02. In: CONGRESSO BRASILEIRO DE SOJA, Resumos... Foz do Iguaçu, PR., 2002. p. 94. 
